\title{
Pulmonary Function, Aerobic Capacity, Obesity and Stress Level in Bus Drivers and Conductors in Gujarat State Road Transport Corporation: An Evidence Based Study
}

\author{
Anand Jagdishchandra Patel ${ }^{1}$, Anjali Ravindra Bhise ${ }^{2}$ \\ ${ }^{1}$ M.P.T. (Cardio-Respiratory), \\ ${ }^{2}$ M.P.T. (Cardio-Respiratory), Ph.D. Senior Lecturer, Government Spine Institute and Government \\ Physiotherapy College, Civil Hospital, Asarwa, Ahmedabad
}

Corresponding Author: Anand Jagdishchandra Patel

\begin{abstract}
Background: In rapidly growing cities there is increased use of motor vehicles. Bus drivers are exposed to toxic gases from the diesel exhaust and atmospheric pollutants, there is an increased risk of decrease in pulmonary function in bus drivers as well as bus conductors. They have irregular shift patterns; prolonged period of driving in congested areas there is an increased stress level thus an increase in cardiovascular risk factors in bus drivers. Due to prolonged period of sitting during driving and irregular meals there is increased risk of obesity in bus drivers and conductors.

Purpose: To conduct an evidence based study to find whether pulmonary function, aerobic capacity, obesity and stress level is increased bus drivers and conductors in Gujarat state.

Methodology: The study was conducted according to Preferred Reporting Items for systematic reviews and meta-analysis guidelines. Evidences selected since year 1994February 2020 from PubMed, Google Scholar, Physiotherapy Evidence Database (PEDro), ResearchGate, Science Direct and Cumulative Index of Nursing and Allied Health Literature. Key words used were: Pulmonary function test, Aerobic capacity, Stress level, Obesity, Bus drivers and Bus conductors. Analysis was done using Modified Sackett Scale Version 4.0. Total 30 articles were found, out of which 20 articles were relevant and from those 14 articles were included in the study and other articles were excluded as per eligibility criteria.
\end{abstract}

\section{Results:}

- 8 studies showed high prevalence of reduced lung volumes.

- 2 studies showed prevalence of high level of stress.

- 2 studies showed prevalence of Overweight and obesity.

Conclusion: Based on evidences from search engines like Google scholar, PubMed, PEDro, Science Direct and ResearchGate from the year 1994- 2020, it can be concluded that bus drivers and conductors may suffer from chronic respiratory disease, high stress level and may have obesity and there is no evidence on aerobic capacity.

Key words: Pulmonary function test, Aerobic capacity, Stress level, Obesity, Bus drivers and Bus conductors.

\section{INTRODUCTION}

Increased use of motor vehicles has resulted in highly significant percentage of air particles release by diesel exhaust. Diesel exhaust fumes contain many toxic substances including carbon monoxide, nitrous gases, sulfur oxides, aldehydes, and hydrocarbons. ${ }^{[4]}$ Epidemiologic studies of transportation workers involve complex environments since workers are exposed to the many (known and suspected) toxic components of diesel exhaust, cigarette smoke, and other atmospheric pollutants, as 
well as to the physical and psychological stresses of their employment. ${ }^{[1]}$

Epidemiological studies from different parts of the world have consistently identified the relation between air pollution level and health outcomes, including exacerbation of asthma, chronic bronchitis, respiratory tract infections, ischemic heart disease and stroke. The automobile exhaust health effect varies in degree of severity, covering minor effects to serious illness, as well as premature death. Bus drivers are exposed to these pollutants in large amount. These pollutants have a direct effect on the respiratory and cardiovascular system. $\mathrm{NO}_{2}$ and $\mathrm{SO}_{2}$ affect lung function adversely. ${ }^{[3]}$ They are also be exposed to occupational risk factor such as shift work, long working hours, loud noise, carbon monoxide and chemical materials which increase the probability of developing cardiovascular disease. These occupational factors can worsen blood pressure, total cholesterol, Low Density Lipoproteincholesterol, High Density Lipoproteincholesterol, triglyceride, diabetes, abdominal obesity resulting in higher risk of experiencing cardiovascular event among professional drivers. ${ }^{[3]}$

Moreover, they are likely to be obese as they burn less calories due to long sitting hours of their work activities, have poor and irregular diet and have to work in a sitting posture for long periods every day. ${ }^{[3]}$

There are many cases of substance abuse including alcohol and cigarettes as a means of easing psychological problems like anxiety and depression. ${ }^{[3]}$ The job of operating public transit vehicles is amongst the most stressful and unhealthy of modern occupations. Occupational stress is believed to play a significant role in causing cardiovascular, gastrointestinal disorders and musculoskeletal disorders. Bus driving is particularly a stressful job, which has high psychological demands and little decisionmaking control, in combination with low social support on the job.

\section{METHODOLOGY}

Study Type: This is An Evidence Based Study was conducted according to Preferred Reporting Items for Systematic Reviews and Meta-analysis (PRISMA) guidelines (Figure 1).

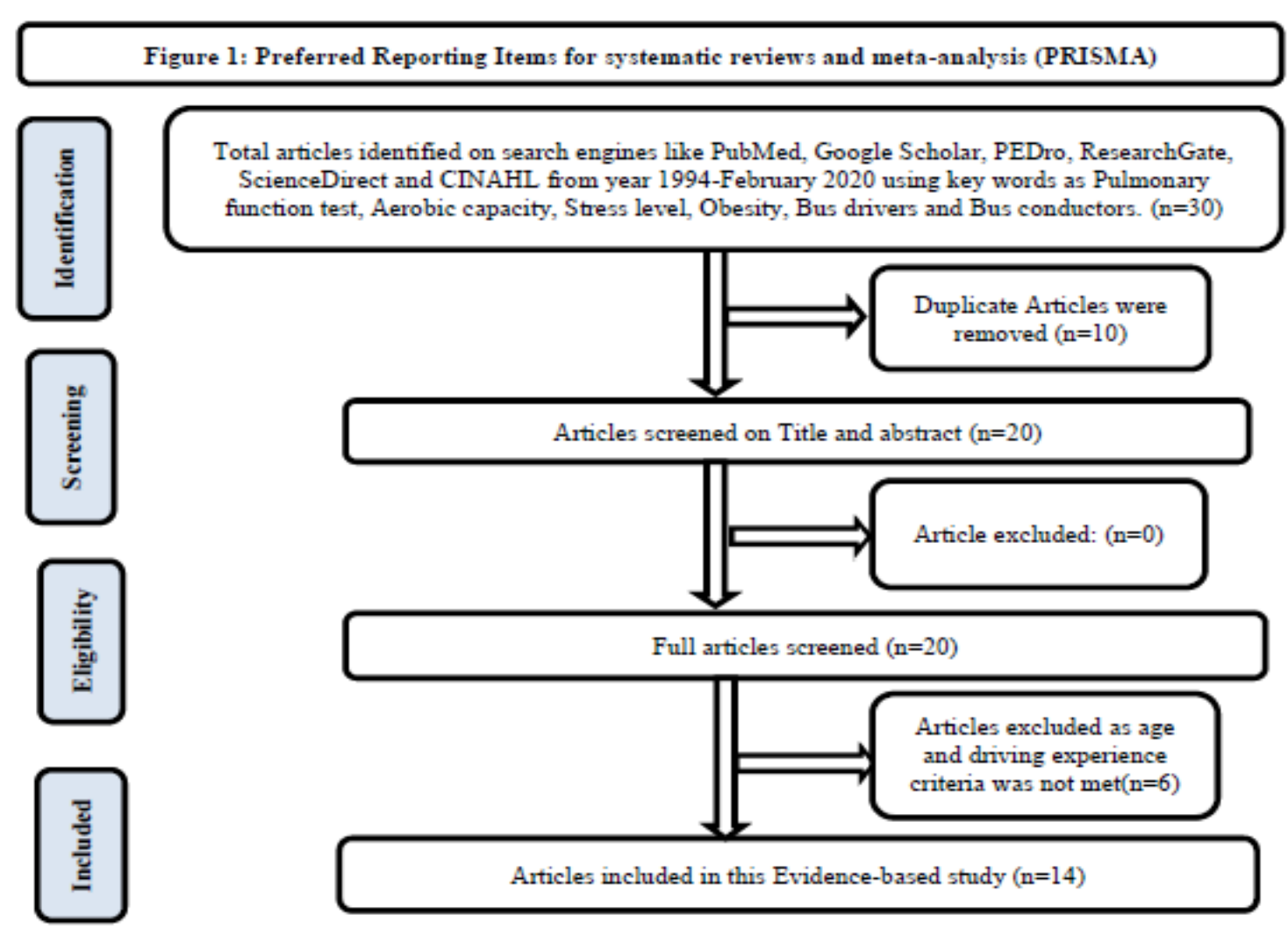


Anand Jagdishchandra Patel et.al. Pulmonary function, aerobic capacity, obesity and stress level in bus drivers and conductors in Gujarat State Road Transport Corporation: an evidence based study

Search strategy: The search engines used for the finding out appropriate articles were: Google Scholar, PubMed, PEDro, ScienceDirect, ResearchGate, CINAHL

Key words used for the search were: Pulmonary function test, Aerobic capacity, Stress level, Obesity, Bus drivers and Bus conductors.

\section{Eligibility criteria: Articles were} selected from 1994-February 2020. Total 30 articles were found, out of which 20 articles were relevant and from those 14 articles were included in the study (Table 1). Other articles were excluded because it didn't met the age and driving experience criteria.

Data Analysis: All 30 articles were assessed using Modified Sackett scale 4.0 scale:

(1) Modified Sackett scale 4.0: The levels of evidence used to summarize the findings are based on the levels of evidence developed by Sackett et al. (2000). (Appendix 1)

Table 1: Characteristics of included studies

\begin{tabular}{|c|c|c|c|c|c|}
\hline $\begin{array}{l}\text { SR } \\
\text { No. }\end{array}$ & Title & $\begin{array}{c}\text { Study design } \\
\text { \& duration }\end{array}$ & $\begin{array}{l}\text { Articles Or } \\
\text { Sample Size }\end{array}$ & Outcome Measures & $\begin{array}{l}\text { Level Of } \\
\text { Evidence }\end{array}$ \\
\hline 1 & $\begin{array}{l}\text { Respiratory Symptoms and Lung Function in Bus } \\
\text { Drivers and Mechanics (1994) })^{[1]}\end{array}$ & $\begin{array}{l}\text { Observational } \\
\text { study }\end{array}$ & $\begin{array}{l}116 \text { bus } \\
\text { drivers } \\
119 \\
\text { mechanics }\end{array}$ & $\begin{array}{l}\text { British Medical Research } \\
\text { Council questionnaire } \\
\text { Spirometer }\end{array}$ & 5 \\
\hline 2 & $\begin{array}{l}\text { Respiratory health of bus drivers in Hong Kong } \\
(2005)^{[10]}\end{array}$ & $\begin{array}{l}\text { Observational } \\
\text { study }\end{array}$ & $\begin{array}{l}358 \text { ACB } \\
\text { drivers } \\
119 \text { NACB } \\
\text { drivers } \\
\end{array}$ & Spirometer & 5 \\
\hline 3 & $\begin{array}{l}\text { Cardiovascular Disease Risk of Bus Drivers in a } \\
\text { City of Korea }(2013)^{[3]}\end{array}$ & $\begin{array}{l}\text { Observational } \\
\text { study }\end{array}$ & $\begin{array}{ll}433 & \text { bus } \\
\text { drivers } & \\
\end{array}$ & $\begin{array}{l}\text { Blood pressure } \\
\text { Framingham risk score }\end{array}$ & 5 \\
\hline 4 & $\begin{array}{l}\text { Occupational stress and its associated health } \\
\text { disorders among bus drivers }{ }^{[5]}\end{array}$ & $\begin{array}{l}\text { Observational } \\
\text { study }\end{array}$ & 230 & $\begin{array}{l}\text { Stress- } \quad \text { related health } \\
\text { complaints questionnaire }\end{array}$ & 5 \\
\hline 5 & $\begin{array}{l}\text { Evaluation of perceived stress in bus drivers of } \\
\text { Pune city }{ }^{[7]}\end{array}$ & $\begin{array}{l}\text { Observational } \\
\text { study }\end{array}$ & 260 & Perceived stress scale (PSS) & 5 \\
\hline 6 & $\begin{array}{l}\text { Occupation exposed to road-traffic emissions and } \\
\text { respiratory health among Congolese transit } \\
\text { workers, particularly bus conductors, in Kinshasa: } \\
\text { a cross-sectional study }{ }^{[2]}\end{array}$ & $\begin{array}{l}\text { Observational } \\
\text { study }\end{array}$ & 517 & $\begin{array}{lr}\text { American } & \text { Thoracic Society } \\
\text { respiratory } & \text { symptom } \\
\text { questionnaire } & \\
\text { Spirometry } & \\
\end{array}$ & 5 \\
\hline 7 & $\begin{array}{l}\text { Study of Ventilatory Lung Function Tests Of Bus } \\
\text { Drivers In Pune City }{ }^{[4]}\end{array}$ & $\begin{array}{l}\text { Observational } \\
\text { study }\end{array}$ & 105 & Schiller lung function unit & 5 \\
\hline 8 & $\begin{array}{l}\text { Pulmonary Function Tests in Transport Workers } \\
\text { Within the Ring Road of Kathmandu Valley }{ }^{[6]}\end{array}$ & $\begin{array}{l}\text { Observational } \\
\text { study }\end{array}$ & 78 & Spirometer & 5 \\
\hline 9 & $\begin{array}{l}\text { Traffic Air Pollution and Respiratory Health: A } \\
\text { Cross-Sectional Study among Bus Drivers in } \\
\text { Dakar (Senegal)(2018) }\end{array}$ & $\begin{array}{l}\text { Observational } \\
\text { study }\end{array}$ & 178 & Spirometer & 5 \\
\hline 10 & $\begin{array}{l}\text { Assessment of respiratory morbidity among bus } \\
\text { drivers and conductors of state road transport } \\
\text { corporation, Kochi, Kerala (2019) }{ }^{[13]}\end{array}$ & $\begin{array}{l}\text { Observational } \\
\text { study }\end{array}$ & 300 & $\begin{array}{l}\text { Mini wright peak flow } \\
\text { meter } \\
\text { Portable spirometer } \\
\text { ATS-DLD-78-A } \\
\text { questionnaire }\end{array}$ & 5 \\
\hline 11 & $\begin{array}{l}\text { Overweight, underweight, and obesity among } \\
\text { male long-distance professional drivers in } \operatorname{Iran}^{[11]}\end{array}$ & $\begin{array}{l}\text { Observational } \\
\text { study }\end{array}$ & 36625 & $\begin{array}{l}\text { Anthropometric } \\
\text { measurements include } \\
\text { height, neck circumference } \\
\text { and weight in kg. }\end{array}$ & 5 \\
\hline 12 & $\begin{array}{l}\text { Spirometric Measures of Air Conditioned Drivers } \\
{[19]}\end{array}$ & $\begin{array}{l}\text { Observational } \\
\text { study }\end{array}$ & 80 & Spirometer & 5 \\
\hline 13 & $\begin{array}{l}\text { General Characteristics and Risk Factors of } \\
\text { Cardiovascular Disease among Interstate Bus } \\
\text { Drivers }{ }^{[20]}\end{array}$ & $\begin{array}{l}\text { Observational } \\
\text { study }\end{array}$ & 249 & $\begin{array}{l}\text { Data on anthropometric } \\
\text { characteristics, } \\
\text { systolic and diastolic blood } \\
\text { pressure, } \\
\text { lipid profile, } \\
\text { fasting blood glucose, } \\
\text { meatoscopy, and } \\
\text { audiometry }\end{array}$ & 5 \\
\hline 14 & $\begin{array}{l}\text { High prevalence of hypertension and obesity could } \\
\text { promote early atherosclerosis in bus drivers: } \\
\text { Results of a cross-sectional study conducted in a } \\
\text { romanian company of transport. } \\
\text { Atherosclerosis. }{ }^{[21]}\end{array}$ & $\begin{array}{l}\text { Observational } \\
\text { study }\end{array}$ & 84 & $\begin{array}{l}\text { BMI } \\
\text { Blood pressure }\end{array}$ & 5 \\
\hline
\end{tabular}




\section{RESULTS}

Evidences were reviewed and analysis was done on the basis of Modified Sackett Scale 4.0.

Total 30 articles were found, out of which 20 articles were relevant and from those 14 articles were included in this evidence-based study and other articles were excluded as per eligibility criteria.

All 14 studies were observational studies. Their Level of evidence was 5 .

- There were 8 studies showing high prevalence of reduced lung volumes.

- 2 studies showing prevalence of high level of stress.

- 2 study showing prevalence of overweight and obesity.

- 2 study show high cardiovascular risk in bus drivers.

\section{DISCUSSION}

Total 14 observational studies were included in this evidence based research. The sample size varied from 78 to 36625 subjects. Total of 8 studies were found on the respiratory function in bus drivers. 2 studies on stress level, 2 on obesity level and 1 on cardiovascular risk in bus drivers.

$B$ Ruddel et al $^{[16]}$ reported reduction in mechanical properties of breathing which is attributed to exposure to benzene in vapors of diesel. There might be reduction in FEV1 indicating there might be some obstruction during expiration and decrease in FVC might be due to some degree of restriction being present in respiratory tract of bus drivers.

Zuskin et al in their study observed a significantly higher prevalence of most chronic respiratory symptoms when compared to control workers. Bus drivers and mechanics employed for more than 10 years also exhibited higher frequencies of respiratory symptoms and the ventilatory capacity demonstrated lower values for all parameters.

Anuradha Rajiv Joshi et al. in her study concluded that bus drivers of Pune city might have combined (obstructive and restrictive) nature of lung disease and long term employment as bus drivers may be predominantly associated with Restrictive nature of lung diseases.

Anuradha Rajiv Joshi et al. in her study concluded that PSS score was very high in bus drivers as compared to office staff. This indicates that bus driving is a tremendously stressful job, and effective measure should be taken to reduce stress in bus drivers.

Taklikar C.S et al concluded that most of the bus drivers had moderate to high occupational stress. Blood Pressure, Musculoskeletal morbidity like low back pain, knee pain, neck pain and shoulder pain were more among bus drivers with high stress.

Mohsen et al. in their study concluded that obesity and overweight were prevalent in long distance professional bus drivers.

\section{CONCLUSION}

Based on evidences on following search engines like Google scholar, PubMed, PEDro, Science Direct and ResearchGate from the year 1994- 2020, it can be concluded that bus drivers and conductors suffer from chronic respiratory disease, high stress level and have obesity. No evidence on levels of aerobic capacity was seen.

\section{Abbreviations}

CINAHL: Cumulative Index of Nursing and Allied Health Literature, RCT: Randomized Controlled Trial, PRISMA: Preferred Reporting Items for systematic reviews and meta-analysis, NO2: Nitrogen dioxide, SO2: Sulphur dioxide, ACB: AC bus drivers, NACB: Non AC bus drivers, FVC: Forced vital Capacity, FEV1- Forced Expiratory Volume In 1second, PSS: Perceived stress Scale.

Acknowledgement: None

Conflict of Interest: There is no conflict of interest.

\section{Source of Funding: None}


Ethical Approval: Ethical approval was not required.

\section{REFERENCES}

1. Zuskin, E., Mustajbegovic, J. and Schachter, E., 1994. Respiratory symptoms and lung function in bus drivers and mechanics. American Journal of Industrial Medicine, 26(6), pp.771-783.

2. Mbelambela, E., Hirota, R., Eitoku, M., Muchanga, S., Kiyosawa, H., YasumitsuLovell, K., Lawanga, O. and Suganuma, N., 2017. Occupation exposed to road-traffic emissions and respiratory health among Congolese transit workers, particularly bus conductors, in Kinshasa: a cross-sectional study. Environmental Health and Preventive Medicine, 22(1).

3. Shin, S., Lee, C., Song, H., Kim, S., Lee, H., Jung, M. and Yoo, S., 2013. Cardiovascular Disease Risk of Bus Drivers in a City of Korea. Annals of Occupational and Environmental Medicine, 25(1), p.34.

4. Anuradha Rajiv Joshi, Study Of Ventilatory Lung Function Tests Of Bus Drivers In Pune City. Int J Basic Appl Physiol, 6(1). 2017; 6(1).

5. S., T., 2016. Occupational stress and its associated health disorders among bus drivers. International Journal of Community Medicine and Public Health, pp.208-211.

6. Ghimire, D., Manna, S. and Shrestha, E., 2018. Study Of Ventilatory Lung Function Tests Of Bus Drivers In Pune City. Int $\mathbf{J}$ Basic Appl Physiol, 6(1). 2017;6(1).Tests in Transport Workers Within the Ring Road of Kathmandu Valley. Med Phoenix, 3(1), pp.52-59.

7. Joshi, A. and Vaidya, S., 2017. Evaluation of perceived stress in bus drivers of Pune city. National Journal of Physiology, Pharmacy and Pharmacology, 7(1), p.90.

8. Sylla, F., Faye, A., Diaw, M., Fall, M. and Tal-Dia, A., 2018. Traffic Air Pollution and Respiratory Health: A Cross-Sectional Study among Bus Drivers in Dakar (Senegal). Open Journal of Epidemiology, 08(01), pp.1-13.

9. Bergomi, M., Modenese, A., Ferretti, E., Ferrari, A., Licitra, G., Vivoli, R., Gobba, F. and Aggazzotti, G., 2017. Work-related stress and role of personality in a sample of Italian bus drivers. Work, 57(3), pp.433440 .
10. Jones, A., Lam, P. and Dean, E., 2005. Respiratory health of bus drivers in Hong Kong. International Archives of Occupational and Environmental Health, 79(5), pp.414-418

11. Pourabdian, S., Golshiri, P. and Janghorbani, M., 2020. Overweight, underweight, and obesity among male longdistance professional drivers in Iran. Journal of Occupational Health, 62(1).

12. Yeary, K., Chi, X., Lensing, S., Baroni, H., Ferguson, A., Su, J., Estabrooks, P., Tate, D. and Linnan, L., 2019. Overweight and Obesity Among School Bus Drivers in Rural Arkansas. Preventing Chronic Disease, 16.

13. Mohandas, S., Francis, P., Rakesh, P. and Antony, P., 2019. Assessment of respiratory morbidity among bus drivers and conductors of the state road transport corporation, Kochi, Kerala. Journal of Family Medicine and Primary Care, 8(12), p.3887.

14. Basha, E. and Kaya, M., 2016. Depression, Anxiety and Stress Scale (DASS): The Study of Validity and Reliability. Universal Journal of Educational Research, 4(12), pp.2701-2705.

15. Rudell, B., Ledin, M., Hammarstrom, U., Stjernberg, N., Lundback, B. and Sandstrom, T., 1996. Effects on symptoms and lung function in humans experimentally exposed to diesel exhaust. Occupational and Environmental Medicine, 53(10), pp.658662.

16. Kacmarek R, Stoller J, Heuer A, Chatburn R, Kallet R. Egan's fundamentals of respiratory care.

17. ACSM's guidelines for exercise testing and prescription. Philadelphia: Wolters Kluwer; 2018.

18. Park K. Park's textbook of preventive and social medicine.

19. Prabhavathi, K., Kumar, G.T., Hemamalini, R.V. and Saravana, A. (2016). Spirometric Measures of Air Conditioned Drivers. International Journal of Physiology, 4(2), p.50.

20. Hirata R, Sampaio L, Leitão Filho F, Braghiroli A, Balbi B, Romano $\mathrm{S}$ et al. General Characteristics and Risk Factors of Cardiovascular Disease among Interstate Bus Drivers. The Scientific World Journal. 2012;2012:1-7. 
Anand Jagdishchandra Patel et.al. Pulmonary function, aerobic capacity, obesity and stress level in bus drivers and conductors in Gujarat State Road Transport Corporation: an evidence based study

21. Pop C, Manea V, Matei C, Mos L. High prevalence of hypertension and obesity could promote early atherosclerosis in bus drivers: Results of a cross-sectional study conducted in a Romanian company of transport. Atherosclerosis. 2015;241(1): e166.
How to cite this article: Patel AJ, Bhise AR. Pulmonary function, aerobic capacity, obesity and stress level in bus drivers and conductors in Gujarat State Road Transport Corporation: an evidence based study. International Journal of Science \& Healthcare Research. 2021; 6(3): 230-235. DOI: https://doi.org/10.52403/ijshr. 20210740

\section{APPENDIX 1-Modified Sackett Scale 4.0}

\begin{tabular}{|c|l|l|}
\hline Level & \multicolumn{1}{|c|}{ Research design } & \multicolumn{1}{c|}{ Description } \\
\hline Level 1a & $\begin{array}{l}\text { Randomized Controlled } \\
\text { Trial (RCT) }\end{array}$ & $\begin{array}{l}\text { More than 1 Higher RCT: Randomized Controlled Trial, PEDro score } \geq \text { 6. Includes within } \\
\text { subjects comparison with randomized conditions and crossover designs. }\end{array}$ \\
\hline Level 1b & RCT & 1 Higher Randomized Controlled Trial, PEDro score $\geq 6$. \\
\hline Level 2 & RCT & Lower RCT, PEDro score < 6 \\
\cline { 2 - 3 } & $\begin{array}{l}\text { Prospective Controlled } \\
\text { Trial (PCT) }\end{array}$ & Prospective Controlled Trial (not randomized) \\
\cline { 2 - 3 } & Cohort & $\begin{array}{l}\text { Prospective Longitudinal study using at least 2 similar groups with one exposed to a particular } \\
\text { condition. }\end{array}$ \\
\hline Level 3 & Case Control & A retrospective study comparing conditions, including historical cohorts. \\
\hline Level 4 & Pre-Post & $\begin{array}{l}\text { A prospective trial with a baseline measure, intervention, and a post-test using a single group of } \\
\text { subjects. }\end{array}$ \\
\cline { 2 - 3 } & Post-test & $\begin{array}{l}\text { A prospective post-test with two or more groups (intervention followed by post-test and no re- } \\
\text { test or baseline measurement) using a single group of subjects. }\end{array}$ \\
\cline { 2 - 3 } & Case Series & A retrospective study usually collecting variables from a chart review. \\
\hline \multirow{2}{*}{ Level 5 } & Observational & Study using cross-sectional analysis to interpret relations. \\
\cline { 2 - 3 } & Clinical Consensus & $\begin{array}{l}\text { Expert opinion without explicit critical appraisal, or based on physiology, biomechanics or } \\
\text { "first principles". }\end{array}$ \\
\cline { 2 - 3 } & Case Report & Pre-post or case series involving one subject. \\
\hline
\end{tabular}

